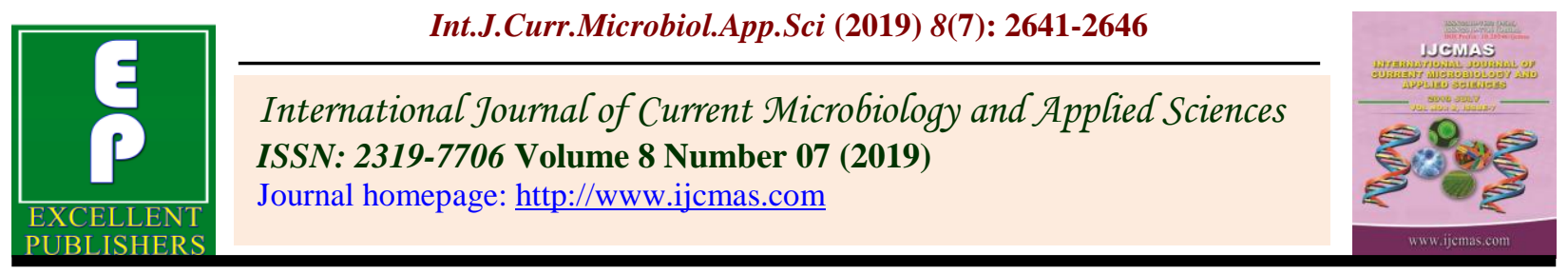

Original Research Article

https://doi.org/10.20546/ijcmas.2019.807.325

\title{
Study on Constraints Affecting the Use of Kisan Mobile Advisory Services in Uttara Kannada District, India
}

\author{
Annapurna F. Neeralgi*, H.M. Santhosha and M.J. Manju
}

ICAR- Krishi Vigyan Kendra, Uttara Kannada, Banavasi Road, Sirsi-581401, India

*Corresponding author

\begin{tabular}{|l|}
\hline K e y w o r d s \\
KMAS, mKisan \\
portal, Agro \\
advisories, KVK \\
\hline Article Info \\
\hline $\begin{array}{l}\text { Accepted: } \\
\text { 20 June } 2019 \\
\text { Available Online: } \\
\text { 10 July } 2019\end{array}$ \\
\hline
\end{tabular}

A B S T R A C T

The study sought to identify the constraints faced by the farmers in using Kisan Mobile Advisory Services (KMAS) in Uttara Kananda district of Karnataka State, registered under http://mkisan.gov.in portal through ICARKrishi Vigyan Kendra, Uttara Kannada, Sirsi. Total of 110 respondents were selected for the study, 10 each from 11 talukas in the district. Factor analysis was used to identify the major constraints that lie inherent in the set of 10 specific constraints that were presented before the respondents for their rankings on a four-point continuum (0 to 3). Computed Problem confrontation Score (CPCS) was developed to make rank order of the constraints. The results of the analysis revealed four major constraints like "Clarification is difficult if any doubt arises, "poor mobile network connectivity", "Language compatibility with the mobile set" and "difficult to understand the technical words in the messages" along with other six constraints. The constraints faced by the respondents - as identified in this study area- must be addressed adequately to enhance the efficacy of KMAS.

\section{Introduction}

Agriculture extension system plays a vital role in dissemination of technologies from lab to land. Due to limited human resource in this system, failure of information distribution on time, handicaps this model. Thus cost effective and efficient communication technologies are required for timely distribution of information, to take lead in this changing agricultural scenario. Information Communication Technologies (ICTs) like TV,
Radio, Telephone and other print media are playing major role in agriculture sector for mass communication of information since early decades. In the present scenario, modern technologies like mobile phones and computer are playing vital role as ICTs and created revolution in agriculture information dissemination.

As part of agricultural extension (extending research from lab to the field), under the National e-Governance Plan - Agriculture 
(NeGP-A), various modes of delivery of services have been envisaged. These include internet, touch screen kiosks, agri-clinics, private kiosks, mass media, Common Service Centres, Kisan Call Centres, and integrated platforms in the departmental offices coupled with physical outreach of extension personnel equipped with pico-projectors and hand held devices. However, mobile telephony (with or without internet) is the most potent and omnipresent tool of agricultural extension. (mKisan Portal)

As per TRAI data of April, 2019 (https://main.trai.gov.in), though there are about 50.99 crore mobile telephone connections in rural areas, internet penetration in the countryside is still low (in single digit percentage). Therefore, mobile messaging is the most effective tool so far having pervasive outreach to nearly 8.93 crore farm families.

mKisan SMS Portal is a mobile based agro advisory service an initiative by Ministry of Agriculture, GOI, started during July 2013 with the aim of sending agriculture information in the form of SMS to the maximum numbers of farmers in their local languages, free of cost. mKisan SMS Portal for farmers enables all Central and State government organizations in agriculture and allied sectors to give information/services/advisories to farmers by SMS in their language, preference of agricultural practices and location.

ICAR KVK Uttara Kannada Sirsi is also one of the beneficiaries of this free service. KVK UK Sirsi has more than 10000 farmers registered in this portal. Need based agro advisories are being disseminated to these farmers since 2013-14.

Table 1 depicts the kisan mobile advisories (KMAS) sent by ICAR KVK Uttara Kannada Sirsi to the registered farmers during 2014-15 to 2018-19 through mKisan portal in Kannada language. The messages sent are broadly categorised into crops, livestock, weather, awareness and other enterprises. Year wise and category wise dissemination of messages reveal that year by year the registered farmers are increasing, which shows the horizontal spread of the popularity of the service. There is increase of $18.39 \%$ in number of farmers registered since 2014-15. The message sent with respect to crop tops the priority with $36 \%$ followed by weather related messages with $25.6 \%$ followed by other enterprises like information on trainings organized, call for awards etc. 6.6\%, awareness $1.6 \%$ and livestock $1 \%$ related messages.

Feedback with respect to the usefulness of the KMAS delivered was received from the farmers; many farmers expressed constraints in using Kisan Mobile Advisories. Hence, this study is mainly focused on the constraints faced by the farmers of Uttara Kannada District in Karnataka in accessing the KMAS in Kannada language disseminated by ICARKVK UK, Sirsi.

\section{Materials and Methods}

\section{Area of study}

Karnataka state comprises of 30 districts, of which Uttara Kannada, Dakshina Kannada and Udupi are in the costal belt. Uttara Kannada district is bounded between $13.769^{\circ}$ to $15.732^{\circ}$ north and $74.124^{\circ}$ to $75.169^{\circ}$ east. It encompasses an area of 10,291 sq km, which is $5.37 \%$ of the total area of the State. The district extends to about $328 \mathrm{~km}$ north south and $160 \mathrm{~km}$ east west. Most of the district is hilly and thickly wooded. The area of the district is $10,222.3 \mathrm{sq} \mathrm{km}$. For administrative purpose, the district has 11 taluks. Supa taluk is the largest with an area of $1890.3 \mathrm{sq} \mathrm{km}$ and Bhatkal Taluk the smallest in district with 348.9 sq $\mathrm{km}$. ICAR KVK Uttara Kannada is 
the pioneer institute for agriculture extension in the district, established by University of Agricultural Sciences, Dharwad under the financial support of ICAR. Need based agro advisories are being sent to registered farmers through https://mkisan.gov.in portal since 2013. The messages sent in regional language Kannada since last 5 years are considered for sake of convenience of the study.

\section{Sampling technique}

Random sampling method was used to select 110 respondents 10 each from 11 talukas of the KVK jurisdiction. The data were collected with the help of structured questionnaire through personal interview of the respondents over phone or in person. The questionnaire included 10 common constraints which were identified during the feedback from farmers during pre-test (Patil et al., 2017).

\section{Measurement of variables}

Constraints faced by the farmers in receiving KMAS through mobile SMS was the focus variable of the study. A four point rating scale weighing $0,1,2$, and 3 for not at all, low, moderate and high respectively was used to explore the extent of constraints faced while using the KMAS. The possible scores of the respondent ranged from 0 to 30 where ' 0 ' indicates the respondent had no problem and ' 30 ' indicate the highest problem. According to the problem confrontation score of individual farmer, the farmers were categorized into three group i.e. Low problem (up to score 7), medium problem (score 8 to $15)$ and high problem (score 16 to 30 ).

For better understanding of the extent of problems faced, Computed Problem confrontation Score (CPCS) was developed to make rank order the problems by the following formula as used by Abu Salem et al., (2017).
$\mathrm{PCS}=\mathrm{Ph} \times 3+\mathrm{Pm} \times 2+\mathrm{Pl} \times 1+\mathrm{Pn} \times 0$

Where,

$\mathrm{PCS}=$ Problem confrontation Score

$\mathrm{Ph}=$ Number of farmers indicating high problem

$\mathrm{Pm}=$ Number of farmers indicating moderate problem

$\mathrm{Pl}=$ Number of farmers indicating low problem

$\mathrm{Pn}=$ Number of farmers indicating no problem at all

\section{Results and Discussion}

The problem confrontation score of the farmers ranged from 1 to 14 against the possible range of 0 to 30 with an average of 6.78 and standard deviation of 2.94. Based on the problem confrontation score, the respondents were classified into three categories i.e., low, medium and high. Distribution of respondents according to their problem confrontation has been shown in Table 2. The data presented that most of the farmers faced low problems (61.82 per cent) in using KMAS while $42 \%$ farmers faced medium problems. Over all, this shows that, the constraints in using the KMAS are not of much worry; this is mainly because of infrastructure facilities in the district, increasing exposure to mobile usage among farming community, dissemination of timely and need based advisories.

For determining the extent of confrontation of individual constraint, rank order was made based on the Computed Problem Confrontation Score as described earlier and arranged in rank order according to their high problem (Table 3). 
The results in the Table 3 revealed that among ten selected constraints "Clarification is difficult if any doubt arises" with PCS 170 ranked first followed by "Poor network connectivity" (PCS 157) then by "Language compatibility with the mobile set" (PCS 123), "Difficult to understand technical words in the message" (PCS 119) and "Incomplete messages" (PCS 74) are the top 5 constraints which are discussed below.

$78.18 \%$ of the respondents reported that after getting a message, if any doubt arises, there is no mechanism to clarify the doubts, the only way is to call back to the KVK which involve cost to them. Most of the time, the sent message doesn't include the contact number for clarification of any query. Poor network connectivity is another major problem in Uttara Kannada district because of the hilly terrain and forest cover. The study revealed that $74.55 \%$ of the respondents opined that poor mobile network is a major constraint in using KMAS. This is because, the district is covered with thick forest and hill areas, most of the villages are in remote places. But in recent days, due to competition among the private mobile service providers, the facilities are being created to reach the remote villages, so farmers are hoping to get good network coverage in coming days. $37.27 \%$ of the respondents are facing problem with incompatibility of Kannada language in their mobile sets. All the respondents who are facing this constraint couldn't access the message as message is not at readable. $60 \%$ farmers opined that it is difficult to understand the technical words in the messages, for example the chemical names are being sent in advisories where farmers are familiar with trade names. 39.09\% farmers expressed that sometimes message will not be complete. The restrictions in characters per message and number of messages per week, restricts KVKs to shorten the advisories to best fit in the allowed character limits.

Table.1 KMAS sent in Kannada language by KVK UKS Sirsi during 2014-15 to 2018-19

\begin{tabular}{|c|c|c|c|c|c|c|c|}
\hline \multirow[t]{2}{*}{ Year } & \multirow{2}{*}{$\begin{array}{c}\text { No. of } \\
\text { Message } \\
\quad \text { s }\end{array}$} & \multicolumn{5}{|c|}{ Category of messages sent } & \multirow{2}{*}{$\begin{array}{c}\text { No. Of } \\
\text { Farmers }\end{array}$} \\
\hline & & Crop & Livestock & Weather & Awareness & $\begin{array}{c}\text { Other } \\
\text { enterprises }\end{array}$ & \\
\hline 2014-15 & 38 & 33 & 0 & 0 & 0 & 5 & 8406 \\
\hline 2015-16 & 68 & 38 & 0 & 27 & 0 & 3 & 9425 \\
\hline 2016-17 & 69 & 37 & 0 & 23 & 3 & 6 & 9440 \\
\hline 2017-18 & 99 & 49 & 5 & 33 & 0 & 12 & 10256 \\
\hline 2018-19 & 80 & 23 & 0 & 45 & 5 & 7 & 10296 \\
\hline
\end{tabular}

Table.2 Distribution of the respondents according to their problem confrontation in using KMAS

\begin{tabular}{|c|c|l|c|c|c|c|}
\hline \multirow{2}{*}{$\begin{array}{c}\text { Possible } \\
\text { range }\end{array}$} & $\begin{array}{c}\text { Observed } \\
\text { Range }\end{array}$ & \multicolumn{1}{|c|}{ Categories } & \multicolumn{2}{|c|}{ Farmers } & \multirow{2}{*}{ Mean } & \multirow{2}{*}{ SD } \\
\cline { 1 - 5 } $\mathbf{0 - 3 0}$ & $1-14$ & Low (0-7) & 68 & 61.82 & 6.78 & 2.94 \\
\cline { 3 - 5 } & & Medium (8-15) & 42 & 38.18 & & \\
\cline { 3 - 5 } & & High (Above 15) & 0 & 0 & & \\
\hline
\end{tabular}


Table.3 Ten selected problems along with problem confrontation index and rank order

\begin{tabular}{|c|c|c|c|c|c|c|c|c|}
\hline \multirow[t]{2}{*}{$\begin{array}{l}\text { Sl. } \\
\text { No }\end{array}$} & \multirow[t]{2}{*}{ Constraints } & \multicolumn{4}{|c|}{$\begin{array}{l}\text { Extent of problem confrontation } \\
\text { of constraints }\end{array}$} & \multirow[t]{2}{*}{ PCS } & \multirow[t]{2}{*}{ Rank } & \multirow[t]{2}{*}{$\begin{array}{c}\% \text { of } \\
\text { Farmers }\end{array}$} \\
\hline & & $\begin{array}{l}\text { Very } \\
\text { High }\end{array}$ & Moderate & Low & Nil & & & \\
\hline 1 & $\begin{array}{l}\text { Clarification is difficult if any } \\
\text { doubt arises }\end{array}$ & 22 & 40 & 24 & 24 & 170 & I & 78.18 \\
\hline 2 & Poor network connectivity. & 20 & 35 & 27 & 28 & 157 & II & 74.55 \\
\hline 3 & $\begin{array}{l}\text { Language compatibility with the } \\
\text { mobile set }\end{array}$ & 41 & 0 & 0 & 69 & 123 & III & 60.00 \\
\hline 4 & $\begin{array}{l}\text { Difficult to understand technical } \\
\text { words in the message. }\end{array}$ & 15 & 23 & 28 & 65 & 119 & IV & 39.09 \\
\hline 5 & Incomplete messages & 9 & 13 & 21 & 72 & 74 & V & 37.27 \\
\hline 6 & $\begin{array}{l}\text { Practical oriented messages could } \\
\text { not be understood through text } \\
\text { message. }\end{array}$ & 4 & 24 & 11 & 84 & 71 & VI & 35.45 \\
\hline 7 & $\begin{array}{l}\text { Information is sometime not } \\
\text { relevant. }\end{array}$ & 0 & 11 & 20 & 79 & 42 & VII & 30.91 \\
\hline 8 & $\begin{array}{l}\text { Irregular charging of mobile due } \\
\text { to electricity problem. }\end{array}$ & 0 & 9 & 20 & 81 & 38 & VIII & 28.18 \\
\hline 9 & Difficult to operate mobile Phone. & 0 & 3 & 31 & 89 & 37 & IX & 26.36 \\
\hline 10 & KMAS were not timely. & 0 & 5 & 21 & 84 & 31 & $\mathrm{X}$ & 23.64 \\
\hline
\end{tabular}

Note: $P C S=$ Problem confrontation score

"Practical oriented messages could not be understood through text message (PCS 71)", "Information is sometime not relevant (PCS 42)", "Irregular charging of mobile due to electricity problem (PCS 38)", "Difficult to operate mobile phones (37)", "KMAS were not timely (31)" were the other constraints faced by the KMAS subscribers.

The study revealed that, the constraints faced by the farmers in using KMAS fall in medium and low confrontation category which is a positive sign. The constraints can be overcome with appropriate solutions like establishment of cost free query resolution system like IVRS, chemical name may be replaced with local nomenclature in the messages which can be addressed by the KMAS agents and by categorising farmers based on their interest to send need based appropriate messages etc.,. Steps are to be taken by the government to strengthen mobile network coverage so as to reach to the rural and remote areas.

\section{Acknowledgement}

I would like to thank ICAR, New Delhi \& ATARI Bangalore, and Zone - XI for extending this platform to send agro advisories to the farmers on cost free basis. I am very much thankful to the farmer respondents who gave me their feedback and information to take up this study.

\section{References}

Abu Salem Asif, Mohammed Nasir Uddin, Debashish Sarker Dev, Md. Abdul Momen Miah: Factors Affecting Mobile 
Phone Usage by the Farmers in Receiving Information on Vegetable Cultivation in Bangladesh, Journal of Agricultural Informatics (ISSN 2061862X) 2017 Vol. 8, No. 2:33-43

Hardevinder Singh Sandhu, Gurdeep Singh and Jagdish Grover, Analysis of Kisan Mobile Advisory Service in South Western Punjab, Journal of Krishi Vigyan:

Majeed, G., Mouneshwari R. Kammar and Siddappa C. Angadi. 2018. Analysis of Kisan Mobile Advisory Text Message
Sent to Farmers of Bagalkot District. Int.J.Curr.Microbiol.App.Sci. $\quad 7(07)$ : 1241-1246.

Mobile Kisan website: https://mkisan.gov.in.

Patil, K.V., V.T. Patel and Prajapati, R.R. 2017. Constraints in Using Kisan Mobile Advisory Service as Perceived by Farmers in Banaskantha District of Gujarat, India. Int.J.Curr.Microbiol.App.Sci. 6(11): 237-240.

Telecom Regulatory and authority of India web portal https://main.trai.gov.in

\section{How to cite this article:}

Annapurna F. Neeralgi, H.M. Santhosha and Manju, M.J. 2019. Study on Constraints Affecting the Use of Kisan Mobile Advisory Services in Uttara Kannada District, India. Int.J.Curr.Microbiol.App.Sci. 8(07): 2641-2646. doi: https://doi.org/10.20546/ijcmas.2019.807.325 